\title{
Genetic Divergence Analysis in Elite Rice (Oryza sativa L.) Germplasm using Agro-morphological Traits
}

\author{
Ankit Kumar*, Rajashekar Reddy, Meghana Devi, B. Jalandhar Ram and B. G. Suresh
}

Department of Genetics and Plant Breeding, SHUATS, Prayagraj, India

*Corresponding author

\section{A B S T R A C T}

\section{Keywords}

Rice, Advanced Breeding Lines, $\mathrm{D}^{2}$ statistics, Divergence, Cluster distance

\section{Article Info}

Accepted:

04 September 2020

Available Online:

10 October 2020
The current experimentation was carried out at the field experimentation centre, Department of Genetics and Plant Breeding, Sam Higginbottom University of Agriculture, Technology and Sciences, Prayagraj, U.P. Thirty two genotypes which include, 29 advanced breeding lines and three checks, were examined for several genetic parameters and genetic divergence among them using $\mathrm{D}^{2}$ statistics for 13 quantitative characters. The analysis divided the 32 genotypes into seven clusters based on Tocher's clustering method. Out of the seven clusters formed, cluster I was the largest with eight genotypes and cluster VI and VII were monogenotypic. Highest inter cluster distance was found between cluster II and cluster IV indicating higher diversity between the genotypes of those clusters. Cluster II had highest mean for test weight character and cluster IV had highest mean for number of tillers per hill, number of panicles per hill and number of spikelets per panicle. Hence, hybridization between genotypes of these clusters would yield transgressive segregants. Highest intra-cluster distance was recorded in cluster V. Test weight had the highest heritability and maximum contribution towards divergence where as number of panicles per hill, flag leaf width, number of spikelets per panicle, biological yield and grain yield per hill had no contribution towards divergence.

\section{Introduction}

Rice belongs to the genus Oryza and the tribe Oryzeae of the family Gramineae (Poaceae). The genus Oryza contains 24 recognized species, of which 22 are wild species and two cultivated species are $O$. sativa and $O$. glaberrima. Rice (Oryza sativa L.) is one of the staple cereal crops of the world, directly feeding more people than any other crop. It is considered as the 'Grain of Life' because it is not only the stable food for more than $70 \%$ of the Indians but also a source of livelihood for about 120 million households. In India, rice is grown in $44.16 \mathrm{~m} . h \mathrm{~h}$, the production level is 115 million tonnes and the productivity is about 2700kg/ha during 2018-19 (Annual report - NRRI-2019). In India, West Bengal stands top in the production of rice with an area of 5.12 m.ha. (11.68\% of entire area across India) with production of 14.97 million tonnes $(13.26 \%$ of entire production) and productivity of $2926 \mathrm{~kg} / \mathrm{ha}$. (Agriculture statistics at a glance - 2018, DAC\&FW, GoI). Uttar Pradesh ranks second in the country in production of rice covering $5.91 \mathrm{~m}$.ha. 
(13.28\% of nation's share) with a production of 13.27 million tons $(11.75 \%$ of entire production) and productivity of the state is around $2.2 \mathrm{t} / \mathrm{ha}$ (Agriculture statistics at a glance-2018).

Knowledge of existing genetic divergence in a plant population is of utmost importance in any any crop improvement programme. Parents identified on the basis of divergence for any breeding programme would be more promising (Kwon et al., 2002). Thus, the present study aims at studying the genetic variability using parameters like GCV, PCV, heritability, genetic advance and identifying parents with high genetic divergence to use them in future hybridization programmes.

\section{Materials and Methods}

The present investigation was carried out in the Field Experimentation Centre of Department of Genetics and Plant Breeding, Naini Agricultural Institute, Sam Higginbottom University of Agriculture, Technology and Sciences, Prayagraj, U.P during kharif-2019. The experimental materials for the present study consisted of 29 ABLs and three check varieties namely NDR359, Jaya and SHIATS DHAN 1 of rice received from the Department of Genetics and Plant Breeding, SHUATS, Prayagraj conducted during kharif-2019. Standard agronomic practices were followed to ensure a good crop. Seedlings were transplanted at a spacing of $15 \times 20 \mathrm{~cm}$. observations were recorded on five randomly selected plants per replication for 13 quantitative characters namely days to $50 \%$ flowering, plant height (cm), number of tillers per hill, number of panicles per hill, panicle length $(\mathrm{cm})$, flag leaf length $(\mathrm{cm})$, flag leaf width $(\mathrm{cm})$, number of spikelets per panicle, days to maturity, biological yield $(\mathrm{g})$, harvest index $(\%)$, test weight $(\mathrm{g})$ and grain yield per hill $(\mathrm{g})$. The experimental data thus recorded on these characters were subjected to statistical and biometrical analysis for analysis of variance (Fisher, 1936), different genetic parameters like Coefficient of variation (GCV, PCV) (Burton, 1952), estimation of heritability (Burton and De Vane, 1953), genetic advance (Johnson, et al., 1995), and genetic divergence among the advanced breeding lines based on Mahalanobis $\mathrm{D}^{2}$ statistics. The 32 genotypes under study were divided into seven clusters based on Tocher's method of clustering. Statistical analysis was performed using Windostat version 9.3

\section{Results and Discussion}

The analysis of variance revealed that there was sufficient amount of variability in the population for selection to act upon. The study of genetic parameters reveals that high GCV and PCV were recorded for number of spikelets (28.29 and 35.22 respectively) per panicle where as higher variation between GCV and PCV was also seen for the same character indicating higher amount of environment on it. Test weight character had the highest heritability (99.9\%) followed by days to $50 \%$ flowering $(97.2 \%)$ and days to maturity $(96.5 \%)$. High heritability coupled with high range of genetic advance as percent mean was recorded for the characters number of tillers per hill, number of panicles per hill, number of spikelets per panicle, biological yield and test weight. However, days to $50 \%$ flowering, plant height, panicle length and days to maturity showed high heritability but moderate genetic advance. Similar observations were noted by Prajapati et al., (2011). The table of ANOVA and summary of genetic parameters under study has been enlisted in table 1 and table 2 respectively.

The divergence studies revealed that the genotypes were divided into 7 clusters (Table 3 ) with cluster being the largest with 8 genotypes and cluster VI and VII had single 
genotypes each. The highest inter cluster distance was found between cluster II and cluster IV (2633.03) followed by cluster II and cluster VI (2308.08). This indicates that the genotypes in these clusters were highly divergent and a crossing programme between these genotypes would yield transgressive segregants (Fig. 1-3).

Table.1 ANOVA for 13 characters of 32 rice germplasm evaluated during kharif 2019

\begin{tabular}{|l|l|c|c|c|}
\hline S.no. & \multicolumn{1}{|c|}{ Characters } & \multicolumn{3}{|c|}{ Mean sum of squares } \\
\cline { 3 - 5 } & & $\begin{array}{c}\text { Replication } \\
\text { (df=2) }\end{array}$ & $\begin{array}{c}\text { Treatments } \\
\text { (df=31) }\end{array}$ & $\begin{array}{c}\text { Error } \\
(\mathbf{d f = 6 2})\end{array}$ \\
\hline $\mathbf{1 .}$ & Days to 50\% flowering & 1.34 & $174.43^{* *}$ & 1.66 \\
\hline $\mathbf{2 .}$ & Plant Height & 25.78 & $273.29^{* *}$ & 7.40 \\
\hline $\mathbf{3 .}$ & Tillers per hill & 0.54 & $10.93^{* *}$ & 1.16 \\
\hline $\mathbf{4 .}$ & Panicles per hill & 0.66 & $8.12^{* *}$ & 0.94 \\
\hline $\mathbf{5 .}$ & Panicle length & 0.98 & $8.67^{* *}$ & 0.68 \\
\hline $\mathbf{6 .}$ & Flag Leaf Length & 1.002 & $57.65^{* *}$ & 4.09 \\
\hline $\mathbf{7 .}$ & Flag Leaf width & 0.001 & $0.044^{* *}$ & 0.004 \\
\hline $\mathbf{8 .}$ & Spikelets per panicle & 566.94 & $7199.82^{* *}$ & 1114.79 \\
\hline $\mathbf{9 .}$ & Days to maturity & 11.46 & $122.75^{* *}$ & 1.44 \\
\hline $\mathbf{1 0}$. & Biological yield & 73.39 & $285.24^{* *}$ & 48.55 \\
\hline $\mathbf{1 1 .}$ & Harvest Index(\%) & 11.53 & $81.81^{* *}$ & 16.77 \\
\hline $\mathbf{1 2 .}$ & Test Weight & 0.35 & $70.62^{* *}$ & 0.03 \\
\hline $\mathbf{1 3}$. & Grain yield per hill & 0.24 & $66.48^{* *}$ & 17.11 \\
\hline
\end{tabular}

** Significant at $1 \%$ Level of Significance

Table.2 Estimation of variability parameters for 13 quantitative traits of rice genotypes evaluated during kharif-2019

\begin{tabular}{|c|c|c|c|c|c|c|c|c|}
\hline S.no. & Character & $\mathbf{V}_{\mathbf{g}}$ & $\mathbf{V}_{\mathbf{p}}$ & GCV & PCV & $\begin{array}{c}\mathbf{h}^{2}(\mathbf{b s}) \\
(\%)\end{array}$ & GA & $\begin{array}{l}\text { GA as } \\
\% \text { mean }\end{array}$ \\
\hline 1. & Days to $50 \%$ flowering & 57.58 & 59.25 & 8.13 & 8.25 & 97.2 & 15.41 & 16.52 \\
\hline 2. & Plant height $(\mathrm{cm})$ & 88.62 & 96.03 & 8.06 & 8.39 & 92.3 & 18.63 & 15.95 \\
\hline 3. & Number of tillers per hill & 3.25 & 4.42 & 19.26 & 22.45 & 73.6 & 3.19 & 34.06 \\
\hline 4. & Number of panicles per hill & 2.39 & 3.34 & 18.15 & 21.44 & 71.7 & 2.69 & 31.66 \\
\hline 5. & Panicle length $(\mathrm{cm})$ & 2.66 & 3.35 & 6.65 & 7.46 & 79.4 & 2.99 & 12.21 \\
\hline 6. & Flag leaf length $(\mathrm{cm})$ & 17.85 & 21.94 & 12.65 & 14.02 & 81.4 & 7.85 & 23.50 \\
\hline 7. & Flag leaf width $(\mathrm{cm})$ & 0.01 & 0.018 & 8.98 & 10.38 & 74.7 & 0.20 & 15.99 \\
\hline 8. & No. of spikelets per panicle & 2028.34 & 3143.14 & 28.29 & 35.22 & 64.5 & 74.52 & 46.82 \\
\hline 9. & Days to maturity & 40.43 & 41.88 & 5.13 & 5.23 & 96.5 & 12.87 & 10.40 \\
\hline 10. & Biological yield(gm) & 78.89 & 127.45 & 16.67 & 21.19 & 61.9 & 14.39 & 27.02 \\
\hline 11. & Harvest index $(\%)$ & 21.68 & 38.45 & 8.65 & 11.52 & 56.38 & 7.2 & 13.38 \\
\hline 12. & Test weight (g) & 23.53 & 23.56 & 20.84 & 20.86 & 99.9 & 9.98 & 42.91 \\
\hline 13. & Grain yield per hill(g) & 16.45 & 33.57 & 14.74 & 21.06 & 49 & 5.85 & 21.27 \\
\hline
\end{tabular}


Table.3 Distribution of 32 genotypes into various clusters

\begin{tabular}{|c|c|c|c|}
\hline S.no. & Cluster number & Number of genotypes & Genotypes included \\
\hline 1. & I & 8 & $\begin{array}{l}\text { SHUATS DHAN (ABL)-03, SHUATS DHAN (ABL)-05, } \\
\text { SHUATS DHAN (ABL)-06, SHUATS DHAN (ABL)-09, } \\
\text { SHUATS DHAN (ABL)-17, SHUATS DHAN (ABL)-20, } \\
\text { SHUATS DHAN (ABL)-21, SHUATS DHAN (ABL)-25 }\end{array}$ \\
\hline 2. & II & 4 & $\begin{array}{l}\text { SHUATS DHAN (ABL)-02, SHUATS DHAN (ABL)- } 11 \text {, } \\
\text { SHUATS DHAN (ABL)-15, SHUATS DHAN (ABL)- } 24\end{array}$ \\
\hline 3. & III & 4 & $\begin{array}{l}\text { SHUATS DHAN (ABL)-01, SHUATS DHAN (ABL)-04, } \\
\text { SHUATS DHAN (ABL)-07, SHUATS DHAN (ABL)-27 }\end{array}$ \\
\hline 4. & IV & 7 & $\begin{array}{l}\text { SHUATS DHAN (ABL)-12, SHUATS DHAN (ABL)-13, } \\
\text { SHUATS DHAN (ABL)-16, SHUATS DHAN (ABL)-18, } \\
\text { SHUATS DHAN (ABL)-19, NDR-359@,SHIATS DHAN-1@ }\end{array}$ \\
\hline 5. & $\mathrm{~V}$ & 7 & $\begin{array}{l}\text { SHUATS DHAN (ABL)-10, SHUATS DHAN (ABL)-14, } \\
\text { SHUATS DHAN (ABL)-22, SHUATS DHAN (ABL)-23, } \\
\text { SHUATS DHAN (ABL)-26, MTU-1001, JAYA@ }\end{array}$ \\
\hline 6. & VI & 1 & BPT-5204 \\
\hline 7. & VII & 1 & SHUATS DHAN (ABL)-08 \\
\hline
\end{tabular}

Table.4 Intra and Inter cluster distances among the seven clusters

\begin{tabular}{|c|c|c|c|c|c|c|c|}
\hline Clusters & I & II & III & IV & V & VI & VII \\
\hline I & $\mathbf{3 2 . 2 1}$ & 590.27 & 278.29 & 824.27 & 141.76 & 765.89 & 253.14 \\
\hline II & & $\mathbf{4 3 . 9 4}$ & 1508.44 & 2633.03 & 512.37 & 2308.08 & 1312.96 \\
\hline III & & & $\mathbf{7 1 . 4 8}$ & 248.31 & 468.11 & 354.78 & 113.05 \\
\hline IV & & & & $\mathbf{7 7 . 8 2}$ & 1033.67 & 194.79 & 302.57 \\
\hline V & & & & & $\mathbf{1 3 9 . 5 6}$ & 797.57 & 304.35 \\
\hline VI & & & & & & $\mathbf{0}$ & 192.42 \\
\hline VII & & & & & & & $\mathbf{0}$ \\
\hline
\end{tabular}

Table.5 Cluster Mean values for 13 quantitative traits in 32 rice genotypes evaluated during kharif-2019

\begin{tabular}{|c|c|c|c|c|c|c|c|c|c|c|c|c|c|}
\hline & $\begin{array}{l}\text { Days to } \\
50 \% \\
\text { flowering }\end{array}$ & $\begin{array}{l}\text { Plant } \\
\text { Height } \\
\text { (cm) }\end{array}$ & $\begin{array}{l}\text { No. of } \\
\text { Tillers } \\
\text { per hill }\end{array}$ & $\begin{array}{l}\text { No. of } \\
\text { panicles } \\
\text { per hill }\end{array}$ & $\begin{array}{l}\text { Panicle } \\
\text { length } \\
\text { (cm) }\end{array}$ & $\begin{array}{c}\text { Flag } \\
\text { Leaf } \\
\text { Length } \\
(\mathbf{c m})\end{array}$ & $\begin{array}{c}\text { Flag } \\
\text { leaf } \\
\text { width } \\
(\mathrm{cm})\end{array}$ & $\begin{array}{c}\text { No. of } \\
\text { spikelets } \\
\text { per } \\
\text { panicle }\end{array}$ & $\begin{array}{l}\text { Days to } \\
\text { Maturity }\end{array}$ & $\begin{array}{l}\text { Biolo } \\
\text { gical } \\
\text { yield } \\
\text { (g) }\end{array}$ & $\begin{array}{c}\text { Harv } \\
\text { est } \\
\text { Index } \\
(\%)\end{array}$ & $\begin{array}{c}\text { Test } \\
\text { Weight } \\
\text { (g) }\end{array}$ & $\begin{array}{c}\text { Grain } \\
\text { yield } \\
\text { per hill } \\
(\mathrm{g})\end{array}$ \\
\hline & 86.96 & 111.02 & & & 24.01 & 30.88 & 1.16 & 135.13 & & 48.59 & 54.22 & & 26.2 \\
\hline Cluster 2 & & & & & & & & & & & & & \\
\hline Cluster 3 & & & & & & & & & & & & & \\
\hline & & & & & & & & & & & & & \\
\hline Cluster 5 & & & 9 & & & & & & & & & & \\
\hline Cluster 6 & 111.67 & & & 9 & 21.47 & 29.45 & 15 & & 141 & 60.4 & 48.2 & 18.03 & 30.73 \\
\hline Cluster 7 & 105 & 121.8 & 7.33 & 7 & 22.77 & 31.63 & 1.4 & 188.67 & 129.67 & 55.87 & 48.47 & 20.95 & 27 \\
\hline
\end{tabular}


Table.6 Percent contribution of each character towards divergence

\begin{tabular}{|c|c|c|c|}
\hline S.no & Source & Contribution (\%) & Times ranked 1st \\
\hline $\mathbf{1}$ & Days to 50\% flowering & 9.27 & 46 \\
\hline $\mathbf{2}$ & Plant height (cm) & 1.41 & 7 \\
\hline $\mathbf{3}$ & Number of tillers/hill & 0.2 & - \\
\hline $\mathbf{4}$ & Number of panicles per hill & 0 & 4 \\
\hline $\mathbf{5}$ & Panicle length (cm) & 0.81 & 1 \\
\hline $\mathbf{6}$ & Flag leaf length (cm) & 0.2 & - \\
\hline $\mathbf{7}$ & Flag leaf width (cm) & 0 & - \\
\hline $\mathbf{8}$ & No. of spikelets/panicle & 0 & 25 \\
\hline $\mathbf{9}$ & Days to maturity & 5.04 & - \\
\hline $\mathbf{1 0}$ & Biological yield (gm) & 0 & 1 \\
\hline $\mathbf{1 1}$ & Harvest index(\%) $(\%)$ & - \\
\hline $\mathbf{1 2}$ & Test weight (g) & 0.2 & - \\
\hline $\mathbf{1 3}$ & Grain yield per hill $(\mathrm{g})$ & 0 & $\mathbf{8 2 . 8 6}$ \\
\hline
\end{tabular}

Fig.1 Histogram depicting percent contribution of each character towards genetic divergence

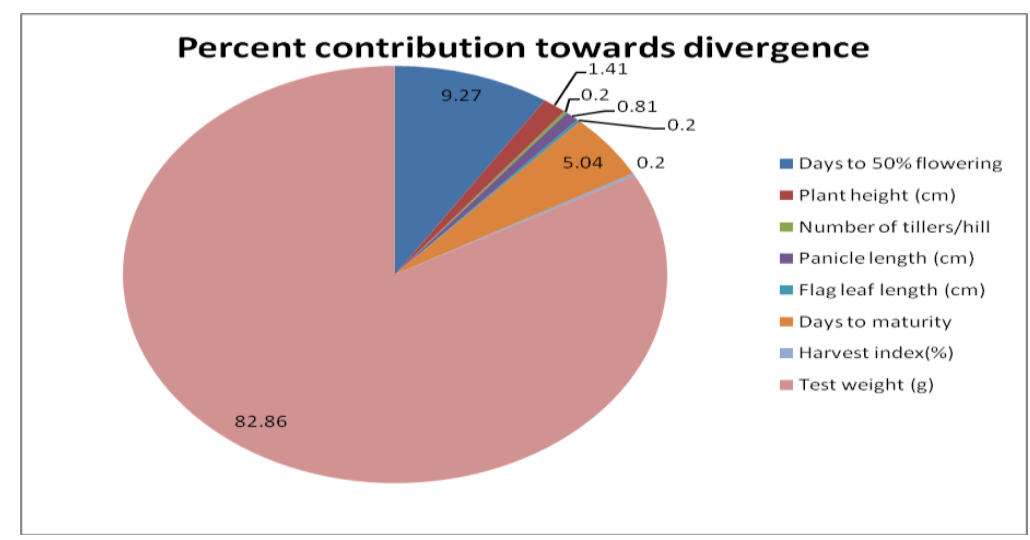

Fig.2 Cluster Diagram depicting relative position of different clusters with intra and inter cluster distances among them

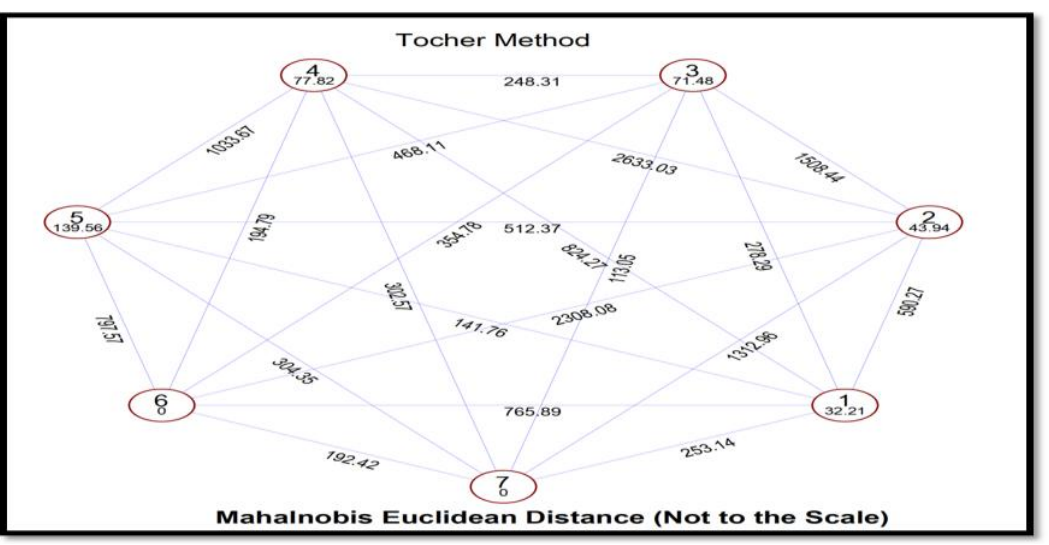


Fig.3 Dendrogram showing clustering pattern of 32 rice genotypes in kharif-2019 using Tocher's method

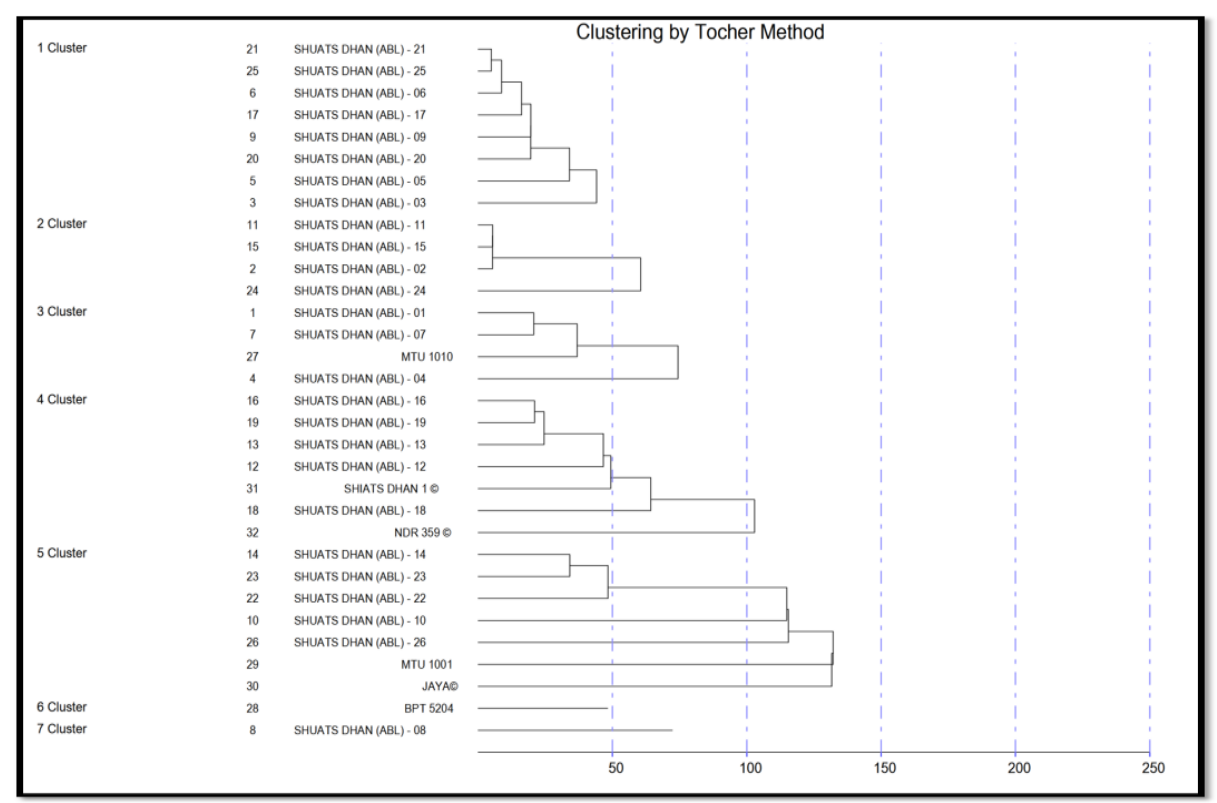

Cluster II showed superiority for test weight (for which the opposite distant cluster IV was inferior) and cluster IV was superior for number of spikelets per panicle, number of tillers per hill and number of panicle per hill. Thus a crossing between these clusters will yield desirable results. Highest intra cluster distance was found for cluster V. Different clusters showed superiority for different characters which indicates that a single cluster can't be used for development of all characters. The intra and inter cluster distances have been tabulated in table 4 .

Mean performance of a cluster is the mean values of individual characters of the genotypes included in it. Analysis of cluster means indicates the existence of considerable differences for mean values in different traits. High cluster mean indicates that the genotypes of the cluster can be used for development of that particular character e.g. Cluster II showed highest mean for test weight which means genotypes of cluster II can be used to develop the test weight character. Per cent contribution of each character towards divergence revealed that test weight $(82.86 \%)$ and days to $50 \%$ flowering $(9.27 \%)$ were the major contributors towards divergence and accounted for about $92.13 \%$ of contribution towards total divergence. These observations come in agreement with the findings of Ramesh Chandra et al., (2010), Iftekharuddaula et al., (2010), Rajesh et al., (2010), N. Chamundeswari (2016) (Table 5 and 6).

In conclusion the current investigation revealed that the genotypes under study had considerable variability among them which enables selection to act upon. The genotype SHUATS DHAN (ABL)-02 was observed the best in terms of grain yield per hill where as SHUATS DHAN (ABL)-20 was the earliest maturing variety (115 days). High GCV and PCV were recorded for number of spikelets per panicle. High magnitude of difference for GCV and PCV were recorded for the same character which indicates higher 
environmental influence. High heritability coupled with high genetic advance as percent mean was recorded for the characters number of tillers per hill, number of panicles per hill, number of spikelets per panicle, biological yield and test weight. This indicates preponderance of additive gene action for these characters. Such combination is desirable as direct selection can be practiced for such characters due to their high heritability and high genetic advance. Highest intra cluster distance was recorded for cluster $\mathrm{V}$ and highest inter cluster distance was recorded between cluster II and cluster IV. Cluster II showed high cluster mean for test weight and cluster IV showed high mean for superior for number of tillers per hill, number of panicles per hill, number of spikelets per panicle. These clusters can be used for development of these characters. Out of all the characters, test weight had the highest contribution towards divergence. The genotypes of clusters II, III, IV, VI can be used for crossings in future hybridization programmes as they have high genetic diversity among them.

\section{References}

Agricultural statistics at a glance, 2018. Ministry of Agriculture \& Farmers welfare, Department of Agriculture, Cooperation \& Farmers welfare, Directorate of Economics and Statistics, Government of India.

Annual Report, Department of Agriculture, Co-operation \& Farmers Welfare (2017-18).

Annual Report, ICAR-National Rice Research Institute (2019)

Arunachalam, Genetic Divergence in Plant Breeding Indian Journal of genetics and Plant Breeding, 41:226-236

Chamundeswari N. Studies on Nature of genetic divergence in rice (Oryza sativa L.) International Journal of Science,
Environment and Technology, 20165 (6) 4018-4023.

Charles Wesley K., M. Nagaraju, Lavanya G.R Estimation of genetic variability and divergence in green gram (Vigna radiata L.) germplasm Journal of Pharmacognasy and Phytochemistry, $20209(2)-1890-1893$.

Falconer, D.S. (1960). Introduction to quantitative genetics Edinburgen and London: Aliver and Bodyd.

Iftekharuddaula KM, Khaleda Akter Hassan M.S., Kaniz Fatema and Anil Badshah Genetic Divergence, Character association and selection criteria in irrigated rice. Online Journal of Biological Sciences, (2010) 2 (4): 243246

Palaniyappan S., Arunachalam P., Bhanumathy S., M.L. Mini and Muthuramu S. Genetic divergence and clustering studies in advanced breeding lines of rice (Oryza sativa L.) Electronic Journal of Plant Breeding, 202011 (2): 499-504

Prajapati, M.K., Singh, C.M., Suresh, B.G., Lavanya, G.R and Jadav, P. Genetic parameters for grain yield and its component characters in rice (Oryza sativa L.). Electronic Journal of Plant Breeding, 2011 2(2):235-238.

Ramesh Babu P., SreeLakshmi Ch. Genetic Divergence studies for yield and yield attributing traits in Rice (Oryza sativa L.) Journal of Rice Research 201710 (1)

Rashmi D., Bisen, P., Saha, S., Loitongbam, B., Singh, S. and Singh, P.K. (2017). Genetic diversity analysis in rice (Oryza sativa L.) accessions using SSR markers. International Journal of Agriculture, Environment \& Biotechnology, 10(4): 457-467

Sneha Gupta, Prashanth Bisen, Sameer Upadhyay, S.R. Rathi, Ganesh Kumar, Singh P.K., Sinha B. Assessment of 
Genetic Divergence in Rice (Oryza sativa L.) germplasm, International Journal of Current Microbiology and Applied Sciences,2020 9 (2): 14991507.

Thippannagari Radha, P. Satheesh Kumar and K. Saravanan Genetic Divergence for Quantitative and Quality Traits in Rice
(Oryza sativa L.) International Journal of Current Microbiology and Applied Sciences, 2018, 7(5): 494-500.

World Agricultural Production (2020), Foreign Agriculture Service Circular Series, United States Department of Agriculture.

\section{How to cite this article:}

Ankit Kumar, Rajashekar Reddy, Meghana Devi, B. Jalandhar Ram and Suresh, B. G. 2020. Genetic Divergence Analysis in Elite Rice (Oryza sativa L.) Germplasm using Agromorphological Traits. Int.J.Curr.Microbiol.App.Sci. 9(10): 92-99.

doi: https://doi.org/10.20546/ijcmas.2020.910.013 